\title{
Kelayakan Finansial Usaha Pengolahan Ubi Kayu Menjadi Tiwul Instan di Desa Wonosari Kecamatan Pekalongan Kabupaten Lampung Timur.
}

\author{
Financial Feasibility of Cassava Processing Business Being Instant Tiwul in \\ Wonosari Village District Pekalongan East Lampung Regency.
}

\author{
Ainul Mardliyah* dan Supriyadi \\ Dosen Pengajar Program Studi Agribisnis STIPER Dharma Wacana Metro \\ Jln Kenanga No 3 Mulyojati 16C Metro, Kota Metro kode pos 34111 \\ Email : ainulsoekoyo@gmail.com
}

\begin{abstract}
This study aims to: 1) Analyze the feasibility of cassava processing business into instant tiwul (KWT Tani Hidup) in Wonosari Village Pekalongan District East Lampung Regency, 2) Know the income of cassava processing into instant tiwul (KWT Tani Hidup) in Wonosari Village Pekalongan District East Lampung Regency. The method of analysis used for the first purpose is financial analysis such as NPV, IRR, Payback Period (PP), Net B / C, and BEP. The second purpose used income analysis. Research location in Wonosari Village Pekalongan District East Lampung Regency. The results of this research can be summarized as follows: 1) Cassava processing business into instant tiwul (KWT Tani Hidup) in Wonosari Village Pekalongan District East Lampung Regency is feasible to be developed and profitable when viewed from financial feasibility from Net Present Value (NPV), worthy business with a positive NPV value is Rp 38,118,538; Internal rate of return (IRR) is 98\%; Gross Benefit Ratio (Gross B/C) is 1.71; Net B/C is 3.92; Profitability ratio (PR) is 1.69; Payback period (PP) is 0.1; and BEP is 1.31 ; 2) Instant tiwul business income (KWT Tani Hidup) in Wonosari Village Pekalongan District East Lampung Regency in one month is Rp. 4.460 .083 / month.
\end{abstract}

Keywords: Cassava processing, Financial feasibility, Instant tiwul.

Disubmit: 21 Desember 2017, Diterima: 5 Januari 2018, Disetujui: 28 Januari 2018

\section{PENDAHULUAN}

Subsektor pangan dan hortikultura salah satu komoditas tanaman pangan yang cukup penting setelah padi dan jagung adalah ubi kayu. Selain dikonsumsi sebagai bahan pangan masyarakat, ubi kayu juga digunakan sebagai bahan baku industri rumah tangga seperti makanan ringan (kelanting) dan Tiwul. Komoditas ubi kayu dapat diusahakan pada lahan kering, hal ini didorong pula oleh mudahnya teknologi budidaya serta kecilnya risiko dalam usahatan ubi kayu sehingga potensi perkembangan agribisnis ubi kayu dipropinsi Lampung sangat besar. Selain itu adanya industri-industri yang memerlukan ubi kayu sebagai bahan baku utama telah mendorong petani untuk berusahatani ubi kayu.

Rata-rata produktivitas Ubi kayu di Propinsi Lampung pada tahun 2014 sebesar 26,55 Ton/Ha (BPS Provinsi Lampung, 2015). Hal ini menunjukkan ubi kayu sangat prospek untuk dikembangkan di Propinsi Lampung. Peranan agroindustri sangat besar dengan usahatani ubi kayu terhadap pendapatan masyarakat dan kesejahteraan masyarakat sehingga tidak semata berorentasi pada peningkatan produksi fisik (Soejono, 2011). Ubi kayu memiliki Potensi nilai ekonomi sebagai pakan ternak, bahan makanan yang dapat dimakan langsung 


\section{Jurnal Penelitian Pertanian Terapan}

(mentah, direbus, atau digoreng), bahan pengganti tepung gandum atau yang dikenal dengan tepung mocaf, dan dijadikan bahan makanan pengganti beras seperti gaplek, oyek, dan tiwul.

Tiwul merupakan makanan yang terbuat dari gaplek menjadi tepung (Rukmini \& Naufalin, 2016). Tiwul merupakan makanan pengganti beras yang memiliki kandungan karbohidrat hampir sama dengan beras. Ubi kayu dapat diolah menjadi beraneka macam makanan yang menyebabkan munculnya usaha pengolahan berbahan baku ubi kayu sehingga pendapatan yang di peroleh akan sangat menguntungkan (Tambunan et al., 2015).

Usaha Pengolahan berbahan baku ubi kayu yang menggunakan bahan baku lokal akan meningkatkan jumlah dan jenis produk yang tersedia di pasar sehingga akan berdampak pada keanekaragaman produksi dan konsumsi, serta dapat meningkatkan penyerapan tenaga kerja dan pendapatan petani di Kabupaten Lampung Timur. Lampung Timur merupakan salah satu kabupaten penghasil terbesar kedua komoditas ubi kayu di propinsi Lampung pada tahun 2014 sebesar 1.433.084 Ton (BPS Provinsi Lampung, 2015).

Tiwul pada zaman dahulu belum tersedia dalam kemasan instan, namun kini sudah tersedia tiwul instan yang dapat dikonsumsi kapan saja dan dapat disimpan dalam waktu yang lama (Zulkarnain, 2017). Hal ini merupakan terobasan baru sehingga tiwul lebih praktis, siap saji, dan mudah didapat. Kelompok Wanita Tani (KWT) di Desa Wonosari Kecamatan Pekalongan Kabupaten Lampung Timur merupakan salah satu kelompok yang mengolah ubi kayu menjadi tiwul.

Kelompok Wanita Tani (KWT) di Desa Wonosari Kecamatan Pekalongan Kabupaten Lampung Timur menggunakan peralatan-peralatan yang dipergunakan industri dalam keadaan baik dan dapat menghasilkan produksi yang sesuai dengan standar yang ditetapkan industri. Peralatan yang dipakai oleh industri merupakan peralatan tradisional dan ada yang canggih. Kendala yang dihadapi dalam usaha pengolahan ubi kayu adalah bahan baku yang berfluktuasi sehingga ketika musim hujan harga ubi kayu akan naik dari harga biasa serta pasar yang terbatas.

Berdasarkan latar belakang tersebut, peneliti ingin meneliti apakah pengolahan ubi kayu menjadi tiwul instan di Desa Wonosari Kabupaten Lampung Timur sudah layak untuk dikembangkan dan berapakah pendapatan usaha tiwul instan (KWT Tani Hidup) di Desa Wonosari Kecamatan Pekalongan Kabupaten Lampung Timur.Adapun tujuan dari penelitian ini adalah : 1) Mengetahui kelayakan usaha pengolahan ubi kayu menjadi tiwul instan (KWT Tani Hidup) di Desa Wonosari Kecamatan Pekalongan Kabupaten Lampung Timur; 2) Mengetahui pendapatan pengolahan ubi kayu menjadi tiwul instan (KWT Tani Hidup) di Desa Wonosari Kecamatan Pekalongan Kabupaten Lampung Timur.

\section{METODE PENELITIAN}

Penelitian dilaksanakan pada KWT Tani Hidup di Desa Wonosari Kecamatan Pekalongan Kabupaten Lampung Timur. Pemilihan lokasi ini dilakukan sengaja (purposive) dengan pertimbangan daerah ini memiliki KWT yang sedang membuat makanan olahan dari ubi kayu. Sampel yaitu anggota KWT Tani Hidup yang aktif dalam kegiatan pembuatan Tiwul instan sebanyak 8 orang. Waktu penelitian dilakukan pada bulan Maret - April 2017. Metode yang digunakan adalah metode survei. Data yang digunakan dalam penelitian ini adalah data primer dan data sekunder. Data primer diperoleh melalui wawancara langsung kepada petani dengan menggunakan kuesioner. Data sekunder didapatkan dari instansi atau lembaga terkait.

Untuk mengetahui kelayakan usaha pengolahan ubi kayu menjadi tiwul instan (KWT Tani Hidup) di Desa Wonosari Kecamatan Pekalongan Kabupaten Lampung Timur dianalisis menggunakan analisis finansial yang meliputi meliputi nilai NPV, IRR (Imron, 2015), Gross B/C, Net B/C, Profitability Ratio (PR), Payback Period (PP), an BEP (Sjahrial, 2008). Dan untuk mengetahui pendapatan pengolahan ubi kayu menjadi tiwul instan (KWT Tani Hidup) di Desa Wonosari Kecamatan Pekalongan Kabupaten Lampung Timur digunakan analisis pendapatan yaitu penerimaan dikurangi dengan total biaya (Suratiyah et al., 2017). 
Mardliyah, A dan Supriyadi : Kelayakan Finansial Usaha Pengolahan Ubi Kayu Menjadi Tiwul Instan ...

\section{HASIL DAN PEMBAHASAN}

Penggunaan Bahan Baku. Penggunaan bahan baku pada usaha pengolahan ubi kayu menjadi tiwul instan ini merupakan gaplek (Ubi kayu yang sudah dikupas dan dikeringkan) dimana dalam satu bulan membutuhkan $600 \mathrm{~kg}$ gaplek atau $3000 \mathrm{~kg}$ ubi kayu yang dijadikan bahan baku. Gaplek tersebut berasal dari Kelompok tani di Desa Wonosari Kecamatan Pekalongan dan sekitarnya. Rata-rata petani menghasilkan $1 \mathrm{~kg}$ gaplek berasal dari $5 \mathrm{~kg}$ ubi kayu. KWT Tani Hidup menggunakan gaplek karena lebih tahan lama dalam proses penyimpanan.

Produksi. Produksi yang dihasilkan dalam pembuatan tiwul instan ini dalam sehari bisa menghasilkan $30 \mathrm{~kg} / \mathrm{hari}$, dimana dalam sebulan hanya mampu beroperasi 20 hari sehingga produksi yang dihasilkan dalam sebulan sebanyak $600 \mathrm{~kg}$ tiwul instan yang siap dipasarkan dengan harga Rp. 10.000 per kilogram. Alat dan perlengkapan yang digunakan dalam kegiatan produksi menggunakan alat - alat yang biasa digunakan oleh masyarakat pada umumnya, sebagai berikut: timbangan elektrik, sealer plastik, tampah, dandang besar, kompor, irig (saringan bambu), dan bak besar.

Penggunaan Tenaga Kerja. Penggunaan tenaga kerja pada usaha pengolahan ubi kayu menjadi tiwul instan meliputi kegiatan penginteran (pembuatan tiwul) dan pengemasan. Tenaga kerja yang diperkerjakan merupakan anggota KWT Tani Hidup yang terdiri dari 2 sampai 3 orang dalam sehari. Setiap hari tenaga kerja mulai datang dan bekerja setelah selesai urusan rumah tangga, biasanya dimulai pukul 10.00-12.00 dan dimulai pukul 14.00-16.00 WIB.

Hasil Penelitian analisis kelayakan usaha dari sisi finansial meliputi nilai indikator $N P V$, IRR, Gross B/C, Net B/C, PR, PP, dan BEP disajikan pada Tabel 1.

Tabel 1. Hasil analisis kelayakan finansial pada usaha pembuatan tiwul instan di Desa Wonosari Kecamatan Pekalongan Kabupaten Lampung Timur.

\begin{tabular}{ccr}
\hline No & Kelayakan Usaha & Keterangan \\
\hline 1 & NPV & 38.118 .538 \\
2 & IRR & $98 \%$ \\
3 & Gross B/C & 1,71 \\
4 & Net B/C & 3,92 \\
5 & PR & 1,69 \\
6 & PP & 0,13 \\
7 & BEP & 1,31 \\
\hline
\end{tabular}

Berdasarkan Tabel 1 terlihat bahwa NPV usaha pembuatan tiwul instan di Desa Wonosari Kecamatan Pekalongan Kabupaten Lampung Timur adalah 38.118.538. Apabila ditinjau dari nilai NPV memberikan nilai NPV positif. Hal ini berarti bahwa usaha pembuatan tiwul instan selama 3 (tiga) tahun investasi memberikan keuntungan sebesar Rp. 38.118.538. Pendekatan indikator NPV dalam kondisi normal (positif) dapat disimpulkan bahwa usaha ini layak dan memberikan manfaat nyata bagi usaha pembuatan tiwul instan di Kabupaten Lampung Timur, hal ini sesuai dengan pernyataan Kusuma, Hidayat, \& Indrianti (2011) yang menyebutkan bahwa nilai NPV yang positif menunjukkan bahwa proyek atau industri tersebut layak dilaksanakan.

Hasil analisis IRR menunjukkan bahwa nilai IRR melebihi dari suku bunga di bank sehingga menginvestasikan modal untuk mengusahakan pengolahan ubi kayu menjadi tiwul instan lebih menguntungkan apabila dibandingkan dengan hanya menyimpan modal, hal ini sesuai dengan Nurainy et al. (2015) yang menyatakan bahwa nilai IRR melebihi rata-rata tingkat suku bunga yang berlaku di bank. Hal ini ditunjukkan dengan nilai IRR dari usaha pembuatan tiwul instan yang dianalisis melebihi rata-rata tingkat suku bunga yang berlaku dibank. Nilai IRR sebesar $98 \%$ memberikan pengertian bahwa dengan menginvestasikan 
modal usaha pengolahan ubi kayu menjadi tiwul instan akan memperoleh pengembalian modal sebesar lebih dari $98 \%$ untuk usaha tersebut.

Apabila ditinjau dari sisi Gross B/C dapat diketahui bahwa usaha pembuatan tiwul instan memberikan nilai Gross B/C lebih dari satu, yaitu 1,71artinya bahwa usaha pembuatan tiwul instan ini selama 3 (tiga) tahun, perbandingan penerimaan dengan biayanya adalah 1,71 . Selain itu, dapat dikatakan usaha pembuatan tiwul instan layak untuk diteruskan.

Apabila ditinjau dari sisi Net B/C dapat diketahui bahwa usaha pembuatan tiwul instan memberikan nilai Net B/C lebih dari satu, yaitu 3,92artinya bahwa usaha pembuatan tiwul instan ini selama 3 (tiga) tahun menguntungkan dengan perbandingan penerimaan dengan biayanya adalah 3,92.Usaha pembuatan tiwul instan layak untuk diteruskan.

Berdasarkan Tabel 1 dapat diketahui bahwa nilai PR lebih dari 1, yaitu 1,69. Artinya usaha pembuatan ubi kayu menjadi tiwul instan layak untuk diteruskan. Untuk nilai PP pada analisis usaha pembuatan ubi kayu menjadi tiwul instan ini yaitu 0,1 . Hal ini berarti total investasi akan kembali dalam tempo waktu 0,1 tahun. Selain itu, nilai PP juga lebih rendah dibandingkan dengan umur ekonomis produksi, jadi dapat disimpulkan pembuatan tiwul instan layak untuk dilanjutkan karena menguntungkan, hal ini sesuai dengan Novia et al. (2013) yang menyatakan bahwa Agroindustri untuk beras siger SU dan SS layak untuk dikembangkan dilihat dari nilai kriteria investasi NPV, IRR, Gross B/C, Net B/C, dan PP menguntungkan untuk diusahakan. Untuk perhitungan Break even point (BEP) dapat diketahui bahwa nilai BEP adalah1,31 yang berarti bahwa total biaya investasi dan biaya operasional akan kembali dengan tempo waktu 1 tahun 3 bulan 16 hari.

Tabel 2. Rata-rata penerimaan, biaya, pendapatan, dan R/C usaha pengolahan ubi kayu menjadi tiwul instan di Desa Wonosari Kecamatan Pekalongan Kabupaten Lampung Timur per 3000 kg ubi kayu per bulan, 2017.

\begin{tabular}{|c|c|c|c|c|}
\hline No & Uraian & Fisik (Kg) & Harga (Rp) & Nilai (Rp) \\
\hline \multirow[t]{2}{*}{1} & Penerimaan & & & \\
\hline & Produksi & 600 & 10.000 & 6.000 .000 \\
\hline \multirow[t]{12}{*}{2} & biaya produksi & & & \\
\hline & Biaya Tunai & & & \\
\hline & Harga gaplek & 600 & 600 & 360.000 \\
\hline & Biaya Cetak & & & 20.000 \\
\hline & Biaya giling & 600 & 700 & 420.000 \\
\hline & Tenaga Kerja & & & 360.000 \\
\hline & Biaya Listrik & & & 22.000 \\
\hline & Biaya lain-lain & & & 100.000 \\
\hline & Total Biaya tunai & & & 1.282 .000 \\
\hline & Biaya Total & & & \\
\hline & Penyusutan & & & 257.917 \\
\hline & Total biaya tunai & & & 1.539.917 \\
\hline \multirow[t]{5}{*}{3} & Pendapatan & & & \\
\hline & Pendapatan biaya tunai & & & 4.718 .000 \\
\hline & Pendapatan biaya total & & & 4.460 .083 \\
\hline & $\mathrm{R} / \mathrm{C}$ biaya tunai & & & 3,68 \\
\hline & $\mathrm{R} / \mathrm{C}$ biaya total & & & 2,90 \\
\hline
\end{tabular}

Hasil penelitian tentang pendapatan usaha pengolahan ubi kayu menjadi tiwul instan di Desa Wonosari Kecamatan Pekalongan adalah penerimaan yang didapat oleh KWT Tani Hidup dikurang dengan biaya produksi per bulan. Biaya produksi yang dikeluarkan untuk setiap terdiri dari biaya tunai dan biaya 
Mardliyah, A dan Supriyadi : Kelayakan Finansial Usaha Pengolahan Ubi Kayu Menjadi Tiwul Instan ...

diperhitungkan. Biaya tunai berasal dari pembelian bahan dasar (ubi kayu/gaplek), biaya tenaga kerja, biaya cetak merk, biaya giling, biaya listrik, dan biaya lain-lain. Biaya diperhitungkan berasal dari penyusutan alat. Dalam sebulan KWT Tani Hidup di Desa Wonosari Kecamatan Pekalongan Kabupaten Lampung Timur hanya memproduksi tiwul instan selama 20 hari.

Penerimaan dari usaha pengolahan ubi kayu menjadi tiwul instan adalah perkalian antara harga jual dan jumlah barang yang dihasilkan per produksi. Analisis perbandingan pendapatan usaha pengolahan ubi kayu menjadi tiwul instan berdasarkan rata-rata penerimaan, biaya, dan pendapatandapat dilihat pada Tabel 2 sebagai berikut.

Berdasarkan Tabel 2 menunjukkan bahwa pendapatan usaha pengolahan ubi kayu menjadi tiwul instan KWT Tani Hidup di Desa Wonosari Kecamatan Pekalongan Kabupaten Lampung Timur per bulan atas biaya tunai sebesar Rp. 4.718.000,00. Nisbah penerimaan terhadap biaya tunai pada usaha pengolahan ubi kayu menjadi tiwul instan sebesar 3,68 artinya setiap Rp. 1,00 biaya tunai yang dikeluarkan akan menghasilkan penerimaan sebesar Rp. 3,68. Nisbah penerimaan terhadap biaya tunai bernilai lebih besar dari 1,00 artinya usaha pengolahan ubi kayu menjadi tiwul instan yang dilakukan oleh KWT Tani Hidup secara ekonomi menguntungkan. Sedangkan pendapatan atas biaya total sebesar Rp. 4.460 .083 per bulan dengan nisbah penerimaan terhadap biaya total sebesar 2,90 artinya setiap $\mathrm{Rp} 1,00$ biaya total yang dikeluarkan akan menghasilkan penerimaan sebesar Rp. 2,90, nisbah penerimaan lebih besar dari 1,00 artinya usaha pengolahan ubi kayu menjadi tiwul instan menguntungkan.

\section{KESIMPULAN DAN SARAN}

Berdasarkan hasil penelitian dan pembahasan maka dapat disimpulkan bahwa usaha pengolahan ubi kayu menjadi tiwul instan (KWT Tani Hidup) di Desa Wonosari Kecamatan Pekalongan Kabupaten Lampung Timur sudah layak dikembangkan dan menguntungkan bila dilihat dari kelayakan finansial dengan pendapatan usaha sebesar Rp. 4.460 .083 per 3000 kg ubi kayu per bulan. Akan tetapi, petani KWT Tani Hidup perlu mengadakan penambahan modal investasi seperti pembelian alat pengering dan alat mencetak butiran tiwul agar investasi yang dikeluarkan lebih efektif. Selain itu perlu dilakukan efisiensi biaya untuk dengan mengurangi biaya tenaga kerja yang dipakai oleh KWT Tani Hidup .

\section{DAFTAR PUSTAKA}

BPS Provinsi Lampung .2015. Luas Panen dan Produksi Ubi Kayu di Kota/Kabupaten 2010- 2014. Lampung.

Imron, A. 2015. Analisis Kelayakan Pemasaran Dan Keuangan UMKM. Jurnal Ekonomi Dan Bisnis, 17(2): $50-62$.

Kusuma, P.T.W.W., Hidayat, D.D. \& Indrianti, N. 2011. Analisis kelayakan finansial pengembangan usaha kecil menengah (UKM) nata de coco di Sumedang, Jawa Barat. 6(1).

Novia, W., Zakaria, W.A. \& Lestari, D.A.H. 2013. Analisis nilai tambah dan kelayakan pengembangan agroindustri beras siger. Jurnal Ilmu-Ilmu Agribisnis, 1(3): 210-217.

Nurainy, F., Nawansih, O. \& Sitanggang, M.M. 2015. Analisis Finansial dan Sensitivitas Usaha Kecil Menengah Dodol Coklat. Jurnal Penelitian Pertanian Terapan, 15(3).

Rukmini, H.S. \& Naufalin, R. 2016. Formulasi Tiwul Instan Tinggi Protein Melalui Penambahan Lembaga Serelia Dan Konsentrat Protein Kedelai. Jurnal Teknologi Industri Pertanian, 25(3).

Sjahrial, D. 2008. Manajemen Keuangan, Edisi 2. 2 ed. Jakarta: Penerbit Mitra Wacana Media.

Soejono, D. 2011. Strategi Pengembangan Agribisnis Dan Agroindustri Sub Sektor Tanaman Pangan Di Kabupaten Situbondo. Jurnal Sosial Ekonomi Pertanian, 5(3): 54-60. 
Suratiyah, K., Sari, P.N., Sofiana, N., Rahmi, R.D. \& Pradeksa, Y. 2017. Agroindustri Pengolahan Tanaman Pangan Di Kecamatan Ponjong Kabupaten Gunung Kidul. Jurnal Sosial Ekonomi Pertanian dan Agribisnis, 11(1): 79-88.

Tambunan, M.A.H., Hasyim, H. \& Maryunianta, Y. 2015. Studi Kelayakan Usaha Pengolahan Tepung Mocaf (Studi Kasus: Desa Baja Ronggi, Kec Dolok Masihul, Kab Serdang Bedagai). JOURNAL ON SOCIAL ECONOMIC OF AGRICULTURE AND AGRIBUSINESS, 3(10).

Zulkarnain, Z. 2017. Analisis Strategi Pengembangan Pemasaran dan Nilai Tambah Tiwul Instan. Journal of Food System and Agribusiness (JoFSA), 1(1): 1-11. 